\title{
STATISTICAL FORECASTING OF SNOW AVALANCHES, SAN JUAN MOUNTAINS, SOUTHERN COLORADO, U.S.A.
}

\author{
By Michael J. Bovis \\ (Institute of Arctic and Alpine Research, University of Colorado, Boulder, Colorado 80302, \\ U.S.A.)
}

Abstract. Meteorological and snow pack variables are measured on chronologically ordered sequences of avalanche and avalanche-free days. Discriminant analysis is used to define a subset of variables which produce an optimal separation of the two multivariate group means. Two seasons are identified in each of the years considered corresponding to periods of dry- and wet-snow avalanches, and form the basic stratification of avalanche days in the analysis. Days are stratified further within each season on the basis of magnitude and number or releases. Weather and snow parameters are integrated over variable time steps prior to each avalanche or avalanche-free day. This introduces a recursive element into the forecast method. Preliminary testing of the method points to its potential in real-time snow avalanche forecasting on a regional basis.

RÉSumÉ. Prévision par voie statistique des avalanches de neige dans les montagnes de San Fuan, Colorado du sud, U.S.A. Des variables météorologiques et nivologiques sont mesurées sur des séquences classées chronologiquement en journées avalancheuses et de non-avalanche. On utilise une analyse discriminante pour définir un sousgroupe de variables qui produit la meilleure séparation possible des moyennes de deux groupes multivariables. Pour chaque année considerée deux saisons correspondant aux périodes d'avalanches sèches et humides forment la distinction de base des journées avalancheuses dans l'analyse discriminante. A l'intérieur de chaque saison les journées sont classées sur la base de l'importance et la nombre d'événements. L'intégration de paramètres météorologiques et nivologiques pour des laps de temps précédent chaque avalanche ou chaque journée sans avalanche, variables, introduit un élément récursif dans la méthode de prévision. Les premiers essais de la méthode montrent leur possibilité dans la prévision des avalanches de neige en temps réel au niveau d'une région.

Zusammenfassung. Statistische Vorhersage von Schneelawinen in den San Juan Mountains, Süd-Colorado, U.S.A. An chronologisch geordneten Tagesfolgen mit und ohne Lawinenabgängen wurden Wetter- und Schneedeckendaten gemessen. Zur Bestimmung einer Datengruppe, mit der sich eine optimale Trennung der beiden vielparametrigen Gruppenmittel vornehmen lässt, wurde eine Selektionsanalyse benutzt. In jedem der betrachteten Jahre wurden zwei Zeitabschnitte festgestellt, dic den Perioden mit Trocken- und Nasschneelawinen entsprechen, und die den Grundauf bau der Lawinentage in der Selektionsanalyse bilden. Innerhalb dieser Abschnitte werden die Lawinentage auf der Grundlage der Gleitlänge und der Zahl der Abgänge der Lawinen untergliedert. Die Integration von Wetter- und Schneeparametern über veränderliche Zeitschritte vor jedem Tag, mit oder ohne Abgang, führt ein rekursives Element in die Vorhersagemethode ein. Eine vorläufige Erprobund der Methode erweist ihre Leistungsfähigkeit für aktuelle Lawinenvorhersagen auf einer regionalen Grundlage.

\section{INTRODUCTION}

The purpose of this paper is to outline the structure and operation of a statistical procedure for the real-time forecasting of snow avalanches over a part of the San Juan Mountains, southern Colorado (Fig. I). Data from the $1972-73$ and $1973-74$ seasons analyzed here are derived from an ongoing snow avalanche project based in Silverton, Colorado. To ensure an accurate timing of events, the analysis is restricted to occurrences along U.S. Highway 550, specifically, the stretch between the gorge of the Uncompahgre River, south to Coal Bank Pass (referred to here as Highway 550). This selection does not restrict the application of the forecast method to a wider area within the San Juan Mountains, since this stretch of the highway contains over i 50 avalanche paths of greatly varying size and activity. Above all, the model described here is designed to provide a regional assessment of avalanche danger and is not calibrated for local factors such as slope aspect. The aspect becomes pertinent when forecasts are prepared for individual slide-paths, but is beyond the scope of this paper.

\section{MethoD}

The snow avalanche season is defined here to lie between the first and last recorded occurrences along Highway 550. Both avalanche and avalanche-free (non-avalanche) days are operationally confined to this season. Within each of the two seasons considered, dry and 


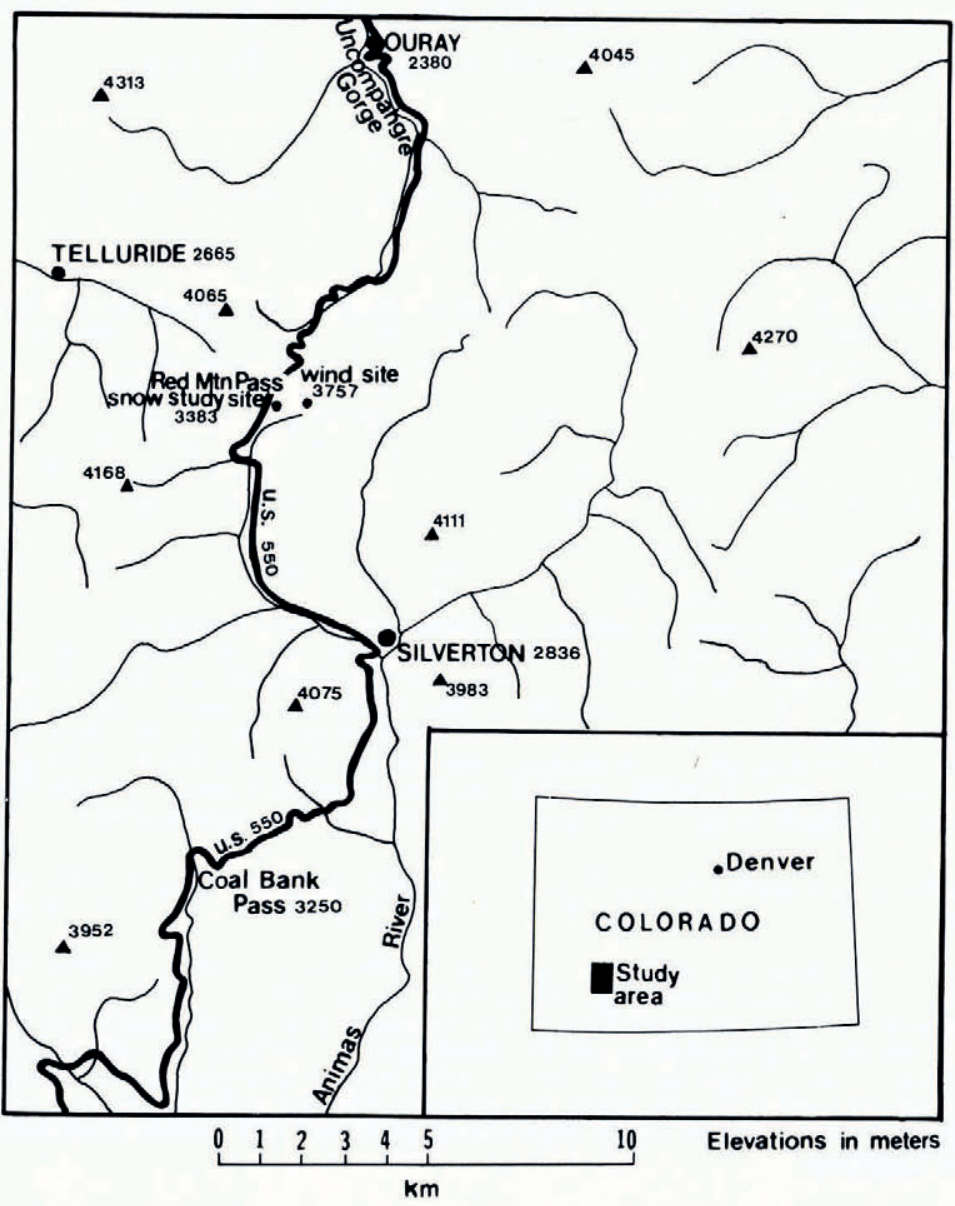

Fig. 1. Location of the study area.

wet avalanche periods are defined by the transition from dry to wet slides (usually abrupt in the San Juan Mountains) based on the U.S. Forest Service slide classification. This partitioning of the avalanche season should be important in forecasting since the two types of slide appear to depend on different antecedent meteorological and snowpack conditions.

The forecast method described here is similar to those presented by Judson and Erickson (1973) and Bois and others ([1975]), in that it is based on linear discriminant functions computed from several meteorological and snowpack variables measured on sets of avalanche and non-avalanche days. By hypothesis, the sets are regarded as mutually exclusive and the purpose of the analysis is to select variables which produce optimal separation of the two sets within a given avalanche season. A bi-variate case is illustrated in Figure 2.

The method presented here differs from those cited above in two important respects: (I) a stratification of avalanche days, stratified by the occurrence of events greater than a certain magnitude, is performed in the dry and wet slide seasons, (2) meteorological and snowpack variables are integrated over different time periods prior to each avalanche or nonavalanche day (Table I). The input variables listed in Table I are based on weather data from the snow-study site maintained at Red Mountain Pass (recording precipitation, air and snow temperature data) and also from the remote windspeed and direction site at $3757 \mathrm{~m}$ 
elevation. These remote data are telemetered to Red Mountain Pass through a buried cable network (see Figure I for locations). This system provides reliable data on weather and snow conditions at an elevation close to that of many avalanche starting zones along Highway 550. Also, real-time data summaries can be prepared at Red Mountain Pass, an important consideration in numerical forecasting.

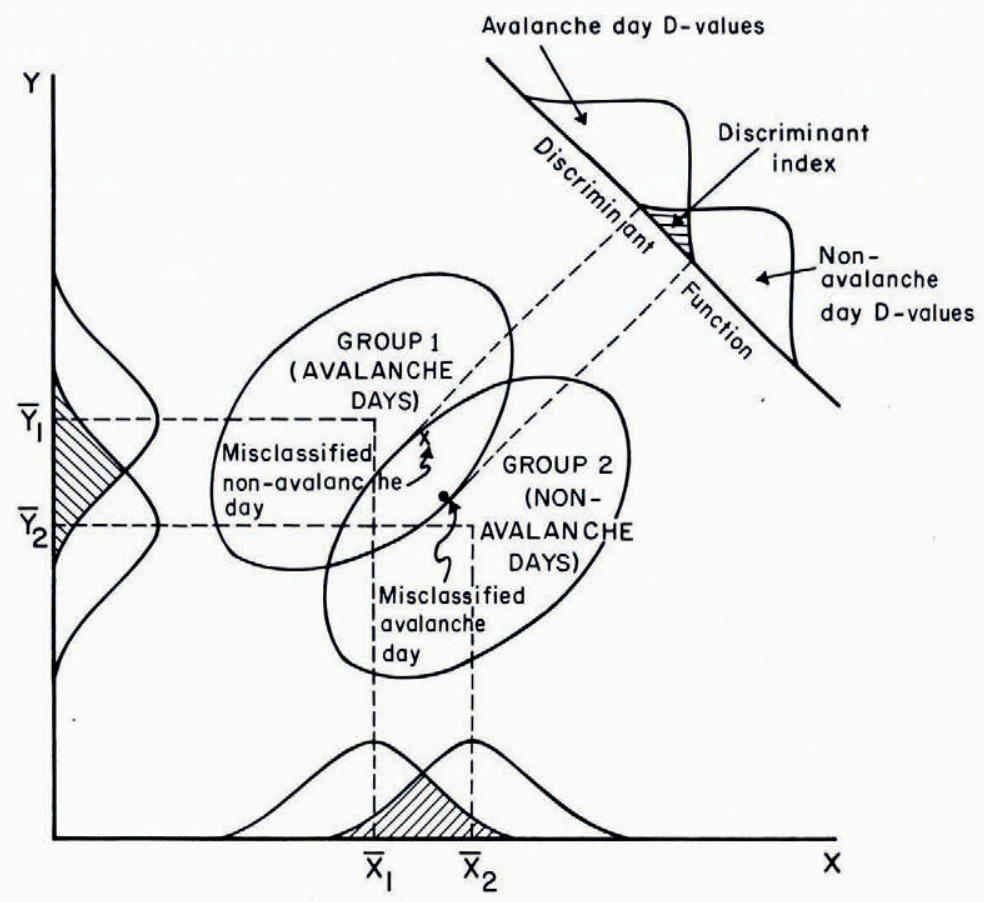

Fig. 2. Discriminant function for a two-group. two-iariable case.

Variable number

4

5

7

8

9

IO

II

I 2

13

TABle I. InPUt Variables

\section{Description}

Total precipitation over an $V^{*}$-day period prior to event or non-event date ( $\mathrm{mm}$ water equivalent)

Total precipitation in the period from $12.00 \mathrm{~h}$ on the day prior to event to $12.00 \mathrm{~h}$ on the event date ( $\mathrm{mm}$ water equivalent)

Maximum $6 \mathrm{~h}$ precipitation intensity in the period from $12.00 \mathrm{~h}$ on the day prior to event to $12.00 \mathrm{~h}$ on the event date ( $\mathrm{mm}$ water equivalent)

Mean $2 \mathrm{~h}$ air temperature over an $\mathcal{N}^{*}$ day period prior to event or non-event date $\left({ }^{\circ} \mathrm{C}\right)$

Mean $2 \mathrm{~h}$ air temperature during same period as $(2)$ above $\left({ }^{\circ} \mathrm{C}\right)$

Maximum $2 \mathrm{~h}$ air temperature in same period as $(2)$ above $\left({ }^{\circ} \mathrm{C}\right)$

Mean $6 \mathrm{~h}$ wind speed over an $\mathcal{N}^{*}$ day period prior to event or non-event date $\left(\mathrm{m} \mathrm{s}^{-1}\right)$

Mean $6 \mathrm{~h}$ wind speed during same period as (2) above $\left(\mathrm{m} \mathrm{s}^{-1}\right)$

Maximum $6 \mathrm{~h}$ wind speed during same period as (2) above $\left(\mathrm{m} \mathrm{s}^{-1}\right)$

Mean temperature gradient in snowpack, 25-50 $\mathrm{mm}$ depth below surface, over an $\mathcal{N}^{*}$ day period prior to event or non-event date $\left({ }^{\circ} \mathrm{C} \mathrm{m}^{-1}\right)$

Mean snowpack temperature at depth $25 \mathrm{~mm}$ below surface over an $\mathcal{N}^{*}$ day period prior to event or non-event date $\left({ }^{\circ} \mathrm{C}\right)$

Mean snowpack temperature at depth $50 \mathrm{~mm}$ below surface over an $\mathcal{N}^{*}$ day period prior to event or non-event date $\left({ }^{\circ} \mathrm{C}\right)$

Snowpack temperature at depth $25 \mathrm{~mm}$ below surface on day prior to event or non-event date $\left({ }^{\circ} \mathrm{C}\right)$

* $\mathcal{N}=2,3$, or $5 \mathrm{~d}$. 
The stratification of avalanche days by the magnitude of avalanches provides a variable operational definition of an avalanche day, although it is constrained by considerations of sample size, as indicated in Table II. The integration of variables over different time periods enables the length of the forecast period to be varied recursively to obtain an optimal value. In this study, periods longer than five days do not improve the separation of avalanche and non-avalanche days. An integration period of, say, ten days, is longer than the interval between most avalanche days, so that variables I, 4, 7, I0, I I, and I2 (Table I) will have approximately the same values in the avalanche and non-avalanche day groups when this time increment is used.

Table II. Stratification of dry and wet avalanche seasons according to avalanche magnitude

\begin{tabular}{|c|c|c|c|c|}
\hline \multirow[b]{2}{*}{ Dry avalanche season } & \multicolumn{2}{|c|}{$1972-73$} & \multicolumn{2}{|c|}{$1973-74$} \\
\hline & $.1 *$ & $\begin{array}{l}\text { Vumber of } \\
\text { variables }\end{array}$ & \multicolumn{2}{|r|}{$\begin{array}{l}\text { Number of } \\
\text { variables }\end{array}$} \\
\hline $\begin{array}{l}\text { 1. All days with dry avalanches. including days with } \\
\text { artillery releases }\end{array}$ & $6 o$ & 9 & $\quad 28$ & 13 \\
\hline $\begin{array}{l}\text { II. Days with natural dry slides greater than or equal to } \\
\text { U.S.F.S. magnitude } 2 \dagger\end{array}$ & 60 & 9 & 25 & 13 \\
\hline $\begin{array}{l}\text { III. Days with natural dry slides, at least three events } \\
\text { greater than or equal to U.S.F.S. magnitude } 2^{+}\end{array}$ & 17 & 9 & 11 & 13 \\
\hline $\begin{array}{l}\text { IV. Days with natural dry slides greater than or equal to } \\
\text { U.S.F.S. magnitude } 3 \dagger\end{array}$ & 13 & 9 & 7 & 13 \\
\hline \multicolumn{5}{|l|}{ Wet avalanche season } \\
\hline $\begin{array}{l}\text { V. All days with wet avalanches, including days with } \\
\text { artillery releases }\end{array}$ & 24 & 9 & 12 & 9 \\
\hline $\begin{array}{l}\text { VI. 1)ays with natural wet slides greater than or equal to } \\
\text { U.S.F.S. magnitude } 2 \dagger\end{array}$ & 17 & 9 & 8 & 9 \\
\hline $\begin{array}{l}\text { VII. Days with natural wet slides, at least three events } \\
\text { greater than or equal to U.S.F.S. magnitude } 2^{+}\end{array}$ & 12 & 9 & 5 & 9 \\
\hline $\begin{array}{l}\text { VIII. Days with natural wet slides greater than or equal to } \\
\text { U.S.F.S. magnitude } 3^{\dagger}\end{array}$ & 15 & 9 & 7 & 9 \\
\hline
\end{tabular}

The integration of variables over different time steps is performed by a routine which requires that raw input variables (e.g. two-hour precipitation and temperature data) reside temporarily on mass storage (disk) files within which calendar months are demarcated by logical records. For each of the three time steps (the two, three, or five days preceding the day in question) a set of variables (Table I) is computed for each day in a chronologically ordered sequence of avalanche and non-avalanche days (Fig. 3). Data are abstracted from the disk files by first skipping the requisite number of logical records on each file, then matching the date of an event with the date on each data file corresponding to the given time integration. If the five-day step is used, for example, the date pointer is positioned five days prior to the avalanche or non-avalanche day in question.

The non-avalanche day set is generally the lenger of the two and is reduced to approximately the same length as the avalanche set by random sampling, as proposed by Bois and others ([1975]). Days with missing variables are eliminated to create a merged output file which becomes the input file for the discriminant analysis. The random sampling of nonavalanche days reduces the degree of statistical dependence which might otherwise exist between members of this group, due primarily to the persistence of a particular weather 


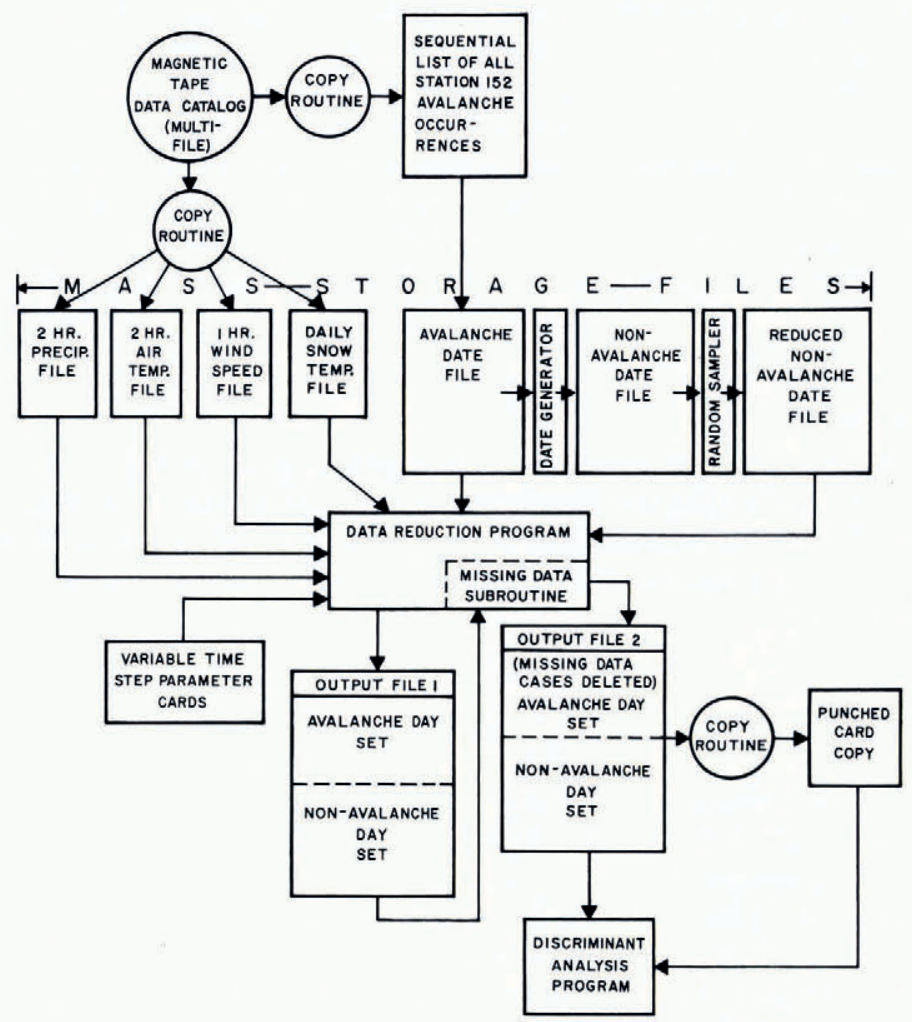

Fig. 3. Information flow during data reduction and discriminant analysis.

pattern. Inclusion of all avalanche days, on the other hand, raises questions as to the statistical independence of days in this group. Dependence might develop due to the removal of snow from starting zones by previous cycles of instability. This would reduce the likelihood of releases in successive days, assuming that the number of releases in a single day is large in comparison to the total population of avalanche paths. It is appropriate to discuss this question, at least from a qualitative standpoint, before proceeding further with the analysis.

A total of 16 I slide-paths have been monitored along Highway 550, many catchment basins larger than $0.15 \mathrm{~km}^{2}$ having up to five separate starting zones. This increases the sample of potential release zones to about 200. In both seasons considered, nearly $70 \%$ of all avalanche days contain from one to five releases only. Therefore a small fraction of the total sample of paths is active on any given avalanche day. Days with 20 or more releases occur on roughly $2 \%$ of all avalanche days, leaving well over 150 zones from which releases can occur. It is worth noting that on such days, a few slide-paths tend to release more than once in twenty-four hours. Often these are paths with starting zones of $0.05 \mathrm{~km}^{2}$ or less which can "recover" quickly from a release due to the rapidity of wind loading in locations close to the timber line. With the exclusion of artillery releases, the occurrence of more than one event per day on larger slide-paths can be traced to releases from separate starting zones. This tendency has led to fatal accidents along Highway $55^{\circ}$.

Many avalanches run to ground as wet slabs during the wet slide season. Since the regeneration of the snowpack to the point of instability is unlikely at this time (although cannot be ruled out), the failure of a large wet slab from a small starting zone prevents this 
slide-path from avalanching further. This constitutes sampling without replacement and reduces the probability of avalanching under otherwise identical conditions. Dependence arising from this situation is offset partly by the possibility of more than one release per day from large, complex starting zones. This is effectively sampling with replacement when observations are made on a slidepath basis rather than that of a starting zone. As the wet slide season draws to a close the sample size is clearly reduced drastically. Although this is undesirable from a statistical point of view, it is of little moment in a hazard forecast since rapid densification of the remaining snow cover brings about a fairly abrupt cessation of avalanching.

\section{Discriminant anALYSis}

We return to the graphical illustration of the method given in Figure 2. A projection of all points is performed such that the Euclidean distance between the two bi-variate means, $P\left(\bar{X}_{1} \bar{Y}_{\mathrm{I}}\right)$ and $P\left(\bar{X}_{2}, \bar{Y}_{2}\right)$, is maximized relative to the degree of spread within the projected points for each group. Following the notation of Hoel (1971, p. I83) this amounts to maximizing the function

$$
G=\frac{\left(\bar{z}_{1}-\bar{z}_{2}\right)^{2}}{\sum_{i=1}^{2} \sum_{j=1}^{n_{i}}\left(z_{i j}-\bar{z}_{i}\right)^{2}},
$$

in which $\bar{z}_{1}, \bar{z}_{2}$ are the means, respectively, of groups one and two (avalanche and nonavalanche), the $i$ subscript refers to groups and the $j$ subscript to items within groups. In Figure 2 the dispersion matrices of both groups are seen to be approximately equal, this enables a pooled variance to be formed in the denominator of Equation (I). Also, the function discriminating between the two groups is a straight line, passing through the points of intersection of corresponding percentile contours in each group. The likelihood ratio is equal to unity along this line, since it is the locus of points that have an equal probability of belonging to either group. When the dispersion matrices are not equal the function discriminating between the two groups is not a straight line; therefore, conventional linear discriminant analysis does not produce an optimum separation of groups (Van der Geer, 1971, chapter 18). In a multivariate situation, it is not feasible to perform a graphical analysis into the form of the likelihood function in order to assess whether or not the linear discriminant assumption is justified. Statistical tests of the equality of dispersion matrices tend to be sensitive to departures from normality in their component variables (Hope, I968, chapter 2). In this study all precipitation and wind-speed variables exhibit pronounced positive skewness so that a $\chi^{2}$ test of homogeneity is likely to give misleading results. A possible solution to the problem is to apply non-linear discriminant analysis techniques, although these are rarely applied and are beyond the scope of this paper. The text of Van der Geer (I97I) is unusual in that it includes a brief treatment of this topic.

Stepwise discriminant analysis is performed first using program $\mathrm{BMD}$ o7 $\mathrm{M}$ from the $\mathrm{BMD}$ Series, University of California, Berkeley. The program is used to define a set of input variables $S$ which make significant contributions to the discriminant process. Significance testing is based on the value of an $F$-statistic:

$$
F=\frac{(\mathcal{N}-2-r+\mathrm{I}) n_{1} n_{2}}{r(\mathcal{N}-2)\left(n_{1}+n_{2}\right)} \cdot D^{2},
$$

where $\mathcal{N}$ is the total number of cases ( $n_{1}$ from group $1, n_{2}$ from group 2), $r$ is the number of variables and $D^{2}$ the square of the Mahalanobis distance between the two multivariate means. A discriminant value $D$ is then assigned to each case in each group from a linear combination of the variables in $S$. The discriminant index $D_{0}$ (Fig. 2) is computed from: 


$$
D_{0}=\frac{1}{2} \sum_{i=1} \lambda_{i}\left(\bar{A}_{i}+\bar{B}_{i}\right)
$$

where $\lambda_{i}$ is the $i$ th coefficient of the discriminant function and $A_{i}, \bar{B}_{i}$ are the mean values of variable $i$ over groups $A$ and $B$. As Figure 2 indicates, $D_{0}$ may be used to classify a future date as either avalanche or non-avalanche by computing a $D$ value from:

$$
D=\lambda_{1} X_{1}+\lambda_{2} X_{2}+\ldots+\lambda_{r} X_{r},
$$

where the $\lambda$ terms are estimated from a previous set of avalanche and non-avalanche days, and the $X$ values are input variables such as those listed in Table I. In a forecast, the $\lambda$ terms are treated as constants and the $X$ values are measured on a real-time basis.

\section{Results}

Results of the discriminant analysis for the $1972-73$ and $1973-74$ seasons are presented under separate sub-headings. This reflects the decision to make no a priori assumptions of similarity between the two seasons. An assessment of such similarity is made in the section "Efficiency of the forecast method".

\section{2-73 season}

Results for this season are summarized in Tables III, IV and V. Variable numbers correspond to those in Table I and are listed in their order of entry into the discriminant function. Two criteria are used to terminate the list: (I) the $F$-value for the significance of group separation falls below the $1 \%$ level; (2) the addition of variables does not improve group separation. In instances where no variable entered produces a significant group separation at the $1 \%$ level, the first three that are significant at the $5 \%$ level are shown. The percentages of misclassified days refer to the number of $D$ values from, say, group I, that lie on the group 2 side of the discriminant index (Fig. 2).

Comparisons based on the first four strata of Table II are summarized in Table III. In each case, variables are integrated over five-, three- and two-day periods prior to each avalanche and non-avalanche day. In line one of Table III, an avalanche day is defined very broadly by the occurrence of at least one slide of any magnitude along Highway 550, irrespective of whether the releases were natural or triggered by artillery. The high percentage of days misclassified in the first three lines of this table is probably due to the assignment of equal weight to all avalanche days. For example, many of the sixty avalanche days in the

\begin{tabular}{|c|c|c|c|c|c|}
\hline & & & & Percentage of & ays misclassified \\
\hline & $\begin{array}{c}\text { Stratum } \\
\text { (see Table II) }\end{array}$ & $\begin{array}{l}\text { Number of } \\
\text { days prior }\end{array}$ & Order of entry of variables & $\begin{array}{c}\text { Avalanche } \\
\text { days }\end{array}$ & $\begin{array}{c}\text { Non-avalanche } \\
\text { days }\end{array}$ \\
\hline I. & I $\mathcal{N}=60,57^{*}$ & 5 & $3,4,5,6$ & 53 & I9 \\
\hline 2. & I $\mathcal{N}=58,57$ & 3 & $3,1,5,4,6$ & 45 & 30 \\
\hline 3. & I $\mathcal{N}=60,5^{8}$ & 2 & $3,5,6,4,1$ & +8 & 28 \\
\hline 4. & II $\mathcal{N}=60,57$ & 5 & $3,4,5,6$ & 53 & 19 \\
\hline 5 . & II $\mathcal{N}=58,57$ & 3 & $3,1,5,4,6$ & 45 & 30 \\
\hline 6 . & II $\mathcal{N}=60,5^{8}$ & 2 & $3,5,6,4,1$ & 48 & 28 \\
\hline 7. & III $\mathcal{N}=17,17$ & 5 & $2 \dagger, 9 \dagger, 7^{\dagger}$ & 53 & 18 \\
\hline 8. & III $\mathcal{N}=17,17$ & 3 & $2 \dagger, 1 \dagger, 4 \dagger$ & 38 & 13 \\
\hline 9 . & III $\mathcal{N}=17,17$ & 2 & $2 \dagger, 9 \dagger, 7 \dagger$ & 53 & 6 \\
\hline 10. & IV $\mathcal{N}=13,13$ & 5 & $8,1,3,9$ & 23 & 8 \\
\hline 11. & IV $\mathcal{N}=13,13$ & 3 & $8,2,5$ & $3^{8}$ & 8 \\
\hline 12. & IV $\mathcal{N}=13,13$ & 2 & $8,2,5$ & 31 & 8 \\
\hline
\end{tabular}

TAble III. Summary of Discriminant analysis: DRy slides, i 972-73

* Numbers refer to avalanche and non-avalanche day samples respectively.

$+F_{0.95}<F<F_{0.99}$. Absence of a dagger indicates $F>F_{0.99}$. 
TABle IV. Summary OF Discriminant ANALysis: Wet SLides, 1972-73

\begin{tabular}{|c|c|c|c|c|c|}
\hline & & & & Percentage of & ays misclassified \\
\hline & $\begin{array}{c}\text { Stratum } \\
\text { (see Table II) }\end{array}$ & $\begin{array}{l}\text { Number of } \\
\text { days prior }\end{array}$ & Order of entry of variables & $\begin{array}{c}\text { Avalanche } \\
\text { days }\end{array}$ & $\begin{array}{c}\text { Non-avalanche } \\
\text { days }\end{array}$ \\
\hline I. & $\mathrm{V} \mathcal{N}=22,10^{*}$ & 5 & No significant $F$-values & & \\
\hline 2. & $\mathrm{~V} \mathcal{N}=24$, Io & 3 & I, 6 & 21 & 20 \\
\hline 3. & $\mathrm{~V} \mathcal{N}=24, \mathrm{II}$ & 2 & $6, \mathrm{I}, 8,9$ & 21 & 18 \\
\hline 4. & VI $\mathcal{N}=17,10$ & 5 & $6 \dagger, 1 \dagger, 7 \dagger$ & 18 & 25 \\
\hline 5 . & VI $\mathcal{N}=19$, I I & 3 & $6+, 1,8$ & 10 & 18 \\
\hline 6. & VI $\mathcal{N}=19 ;$ I I & 2 & $5 \dagger, 1,4,8$ & I6 & I 8 \\
\hline 7 . & VII $\mathcal{N}=$ I0, II & 5 & $5 \dagger, 9 \dagger, 8$ & Io & 20 \\
\hline 8. & VII $\mathcal{N}=11$, 10 & 3 & $5 \dagger, 1,2$ & 18 & 10 \\
\hline 9. & VII $\mathcal{N}=1 \mathrm{I}, \mathrm{II}$ & 2 & $5 \dagger, 1,8$ & o & o \\
\hline I0. & VIII $\mathcal{N}=$ I $3_{3}$, 10 & 5 & 3,8 & 8 & 30 \\
\hline II. & VIII $\mathcal{N}=13$, I0 & 3 & $6 \dagger, 1,4$ & 31 & 40 \\
\hline 12. & VIII $\mathcal{N}=$ I4, II & 2 & $6 \dagger, 4 \dagger, 5 \dagger$ & 14 & 18 \\
\hline
\end{tabular}

first line involved only one event, whereas others had ten or more releases. This is a situation in which inequality of dispersion matrices is likely to occur and thereby affect the outcome of a linear discriminant analysis. The conditions which lead to an avalanche day having only one event are likely to be quite different from those which lead to days which involve a major avalanche "cycle". In contrast, the null condition of non-avalanching does not constitute a mixed population. The stratification of avalanche days according to the magnitude of releases provides a more precise definition of an avalanche day and therefore alleviates the problem of gross inequalities in dispersion matrices.

The importance of maximum six-hour precipitation intensity (variable 3 , Table I) is indicated in each of the three time integrations in lines $\mathrm{I}-3$ in Table III. An optimum separation of avalanche and non-avalanche days is achieved by a three-day integration of meteorological variables, with the total water equivalent over this period being of secondary importance. (A strict physical significance cannot be assigned to the ordinal position of a variable in the linear combination of terms, since its inclusion at a given step of the analysis is contingent upon the variables already in the discriminant function.) Snowpack variables are not included in the $1972-73$ analysis due to discontinuities in the data record.

The sample of days with events of magnitude greater than two on an ordinal scale of five contains the same dates as lines $1-3$; accordingly the results are identical. The operational definition of avalanche days on the basis of at least three events of magnitude two (lines 7-9, Table III) reduces the bias caused by assigning equal weights to days irrespective of the numbers of occurrences. Also, artillery releases are excluded since they may not be related to the same linear combination of antecedent weather conditions used to predict natural releases. None of the three time steps produce significant group separation at the $\mathrm{i} \%$ level but, apart from the three-day integration in which precipitation variables are again prominent, the degree of separation achieved is notably better than in the first three unstratified comparisons.

TABle V. Summary of Discriminant ANALYSIS: DRY AND WET Slides, 1972-73

\begin{tabular}{|c|c|c|c|c|}
\hline \multirow[b]{2}{*}{ Comparison } & \multirow[b]{2}{*}{$\begin{array}{l}\text { Number of } \\
\text { days prior }\end{array}$} & \multirow[b]{2}{*}{ Order of entry of variables } & \multicolumn{2}{|c|}{ Percentage of days misclassified } \\
\hline & & & $\begin{array}{c}\text { Dry avalanche } \\
\text { days }\end{array}$ & $\begin{array}{l}\text { Wet avalanche } \\
\text { days }\end{array}$ \\
\hline $\begin{array}{l}\text { 1. Dry slides versus wet } \\
\text { slides } \\
(\mathcal{N}=30,22)^{*}\end{array}$ & 5 & 4,5 & o & 5 \\
\hline 2. Same $(\mathcal{N}=30,24)$ & 3 & 5,1 & o & 8 \\
\hline 3. Same $(\mathcal{N}=30,24)$ & 2 & 5,7 & 3 & 4 \\
\hline
\end{tabular}


In lines 10-12, a stratification of days by the occurrence of at least one event of magnitude three provides an even better separation of groups although it is based on a reduced sample of only 17 avalanche days. Separation is best at the five-day step and suggests that wind redistribution of snow in the $\mathrm{I} 2 \mathrm{~h}$ to $24 \mathrm{~h}$ period preceding an event (variable 8 ) is an important physical cause of larger releases, given that precipitation totals over the previous four days have been high (variables I, 2 and 3). These two factors are acknowledged to be important contributors to large dry avalanches by practitioners of the more traditional methods of avalanche forecasting. Most of the snow falling during the $\mathrm{I} 2 \mathrm{~h}$ to $24 \mathrm{~h}$ period prior to an event would be available for transportation, since sintering and densification probably require a somewhat longer time. However, the rates of operation of both processes vary markedly with aspect in the San Juan Mountains (lat. $37^{\circ}-38^{\circ}$ N.).

The stratification of wet slides (produced by the failure of an isothermal or quasi-isothermal snowpack) in Table IV follows that for dry slides in Table III. Two notable differences are: (I) sample sizes are smaller in Table IV due to the shorter duration of the wet season; (2) the degree of separation of avalanche and non-avalanche days is generally clearer in the wet slide season. In all but two of the comparisons in Table IV, antecedent air temperature (variables 5 and 6 ) is the first variable entered into the discriminant function. As with dry slides, stratification by magnitude improves group separation although this is at the expense of sample size. Under isothermal snowpack conditions, the mean and maximum two-hour air temperatures in the $12 \mathrm{~h}$ to $24 \mathrm{~h}$ period prior to an avalanche day appear to be the prime determinants of releases. These variables may provide an index of the quantity of free water in the snowpack and hence a measure of progressively reduced cohesion. The secondary importance of precipitation within the five- and three-day integrations suggests that releases are due to an increase in shear stress applied to a snowpack already weakened by the presence of interstitial melt water.

The comparisons in Tables III and IV are based on avalanche versus non-avalanche days. As noted above, the dry and wet slide periods produce substantially different discriminant functions. They are seen to be clearly separable in Table $\mathrm{V}$ where both dry and wet avalanche days are discriminated. For this reason, forecasts could be seriously in error if the dry slide discriminant functions were applied beyond the transition date between the dry and wet seasons. Since this appears to vary by as much as a month from year to year in the San Juan Mountains, both sets of discriminant functions would need to be used from, say, I March until the onset of the "spring" or wet slide cycle. The method is outlined in Figure 4, in which a non-avalanche forecast at step 3 implies that either (I) wet slides are likely to occur; or, (2) neither dry nor wet slides are likely. Complications arise when a rapid transition to wet slides, brought on by a sudden warm trend, is followed by about a week of soft-slab dry releases, followed in turn by a second rapid transition to wet slab or wet loose avalanches signifying the commencement of the wet slide season proper. For this reason, both sets of functions would need to be applied until a few days of continuous wet slide activity have occurred.

\section{I973-74 season}

The numbers of comparisons in Tables VI and VII are fewer than in the previous season due to a much smaller sample of avalanche days within the dry slide period (Table II). Results of the unstratified comparisons within the dry season are broadly similar to those of the previous season. Precipitation statistics in the $12 \mathrm{~h}$ to $24 \mathrm{~h}$ period preceding releases are again of prime importance in group separation. The percentage of misclassifications is notably lower in the $1973^{-74}$ season, although these figures might have been higher had the sample of avalanche days been larger, since a wider range of conditions would have occurred.

Unlike the $1972-73$ season, stratification on the basis of magnitude two improves group separation. Precipitation totals over the $12 \mathrm{~h}$ to $24 \mathrm{~h}$ period prior to releases are again 


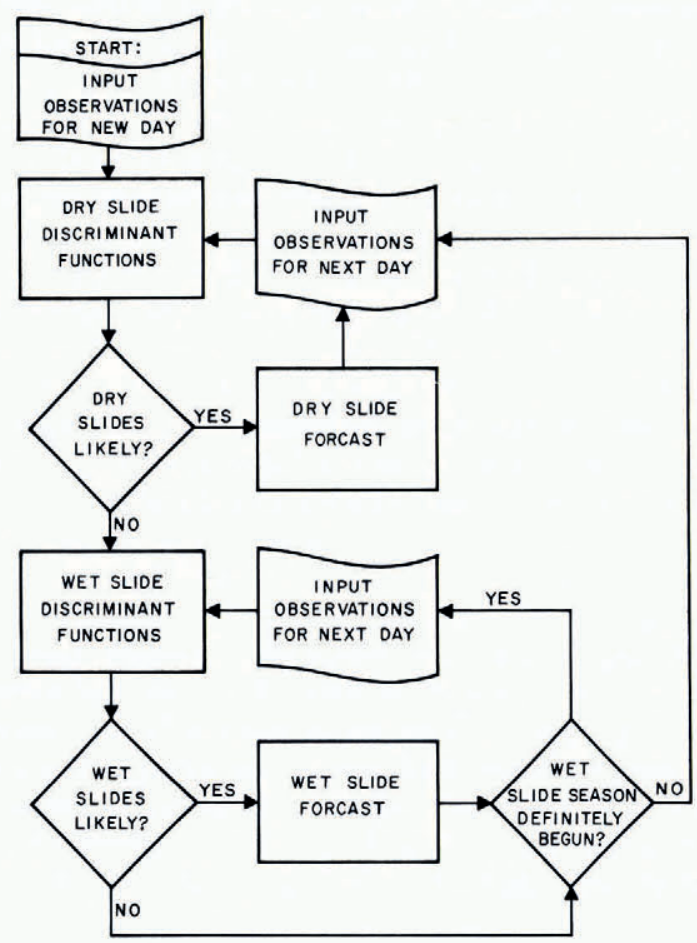

Fig. 4. Flowechart for real-time forecasting of snow acalanches.

TAble VI. Summary of Discriminant analysis: DRy slides, 1973-74

Percentage of sample misclassified

\section{Stratum} (see Table II)

I $\mathcal{N}=24,30^{*}$

I $\mathcal{N}=28,32$

I $\mathcal{N}=28,32$

II $\mathcal{N}=21,30$

II $\mathcal{N}=25,32$

II $\mathcal{N}=25,32$

7. III
Number of days prior

5

3

3
2

5

3

$2,3,5$

$2,3,5$
Order of entry of variables

2, 4, 5, 12

2, 4,5

$2,8,4$

$2,4,5,12$

$2,4,5,13$

$2,8,7,4$

Insufficient sample size

Insufficient sample size
Avalanche Non-avalanche days days

$37 \quad 17$

$\begin{array}{ll}36 & 12 \\ 39 & 10\end{array}$

3910

$\begin{array}{ll}28 & 13\end{array}$

$\begin{array}{ll}32 & 9\end{array}$

* Numbers refer to avalanche and non-avalanche day samples respectively.

TAble VII. Summary of Discriminant analysis: Wet Slides, 1973-74

\begin{tabular}{ll} 
& \multicolumn{2}{c}{ Stratum } \\
& (see Table II) \\
1. & V $\mathcal{N}=12,14^{*}$ \\
2. & $\mathrm{V} \mathcal{N}=12,14$ \\
3. & $\mathrm{V}$ \\
4. & VI $=12,14$ \\
5. & VII \\
6. & VIII
\end{tabular}

Number of days prior

5

3

2

$2,3,5$

2, 3, 5

2, 3,5
Order of entry of variables $8 \dagger, 2 \dagger, 5 \dagger$ $8 \dagger, 2 \dagger, 5 \dagger$ $8 \uparrow, 2 \dagger, 5 \dagger$ Insufficient sample size Insufficient sample size Insufficient sample size

Percentage of sample misclassified

Avalanche Non-avalanche days days

$17 \quad 36$

$\begin{array}{ll}17 & 36 \\ 17 & 36\end{array}$

* Numbers refer to avalanche and non-avalanche day samples respectively.

$\dagger F_{0.95}<F<F_{0.99}$. 
important and are reflected in the number of "direct-action" soft-slab releases within this season. Although the importance of variable 2 in Table VI can be related to slope loading, the interpretation of air temperature is less clear. Precipitation periods in this season are generally associated with a rise in air temperature due to synoptic factors and local latent heat releases. A rise in air temperature concurrent with slope loading may increase the rate of secondary creep in new and old snow, provided that rapid densification and stabilization have not taken place already. This assertion is supported by the observed temperature dependence of the strain-rate and elastic moduli of snow (Bader and Kuroiwa, I962, p. 31 ; Mellor, i968, p. 28).

Only one set of comparisons is listed for wet slides in Table VII, since in other stratifications the number of cases is less than the number of variables (Table II). No physical significance can be attached to variable 8 (mean wind speed in the preceding $24 \mathrm{~h}$ ) since its average value is lower on avalanche days, indicating a higher wind-loading potential on non-avalanche days in this instance.

The direct comparison of dry and wet slide days in Table VIII in large measure reproduces the results of the previous season and underlines the need to test both sets of equations near to the transition date. All the prediction functions are empirically derived, and therefore may not be used legitimately outside their domain.

TABle VIII. Summary of Discriminant ANALYSIS: DRy AND Wet Slides, 1973-74

\begin{tabular}{|c|c|c|c|c|}
\hline \multirow[b]{2}{*}{ Comparison } & \multirow[b]{2}{*}{$\begin{array}{l}\text { Number of } \\
\text { days prior }\end{array}$} & \multirow[b]{2}{*}{ Order of entry of variables } & \multicolumn{2}{|c|}{$\begin{array}{l}\text { Percentage of sample } \\
\text { misclassified }\end{array}$} \\
\hline & & & $\begin{array}{c}\text { Dry-avalanche } \\
\text { days }\end{array}$ & $\begin{array}{c}\text { Wet-avalanche } \\
\text { days }\end{array}$ \\
\hline $\begin{array}{l}\text { 1. Dry slides versus wet } \\
\text { slides } \\
(\mathcal{N}=\text { 15, 12 })^{*}\end{array}$ & 5 & $5,2,1,5$ & 0 & 0 \\
\hline 2. Same $(\mathcal{N}=15,12)$ & 3 & $4,9, \mathrm{I}$ & 7 & 3 \\
\hline 3. Same $(\mathcal{N}=15,12)$ & 2 & $4,9,1$ & 13 & 8 \\
\hline
\end{tabular}

\section{EFFICIENCY OF THE FORECAST METHOD}

The use of an empirically derived forecast model requires that a broad similarity in avalanche controls exists from year to year. The constraint is tested here by using the $1973-74$ data as a test set for the $1972-73$ discriminant functions. In most of the dry-slide comparisons in Table IX non-avalanche days are predicted more accurately than avalanche days. Although the test samples in lines 7-9 are small, the prediction of days with at least three slides of magnitude two or greater is seen to be much more accurate than the predictions in lines $I-3$ and 4-6. Also indicated in Table IX are the numbers of misclassified dry avalanche days, on which two or less events occurred, expressed as a percentage of the total sample of days in a given stratification. When allowance is made for these days, the discriminant functions are seen to provide tolerably accurate predictions on days having several events. The $1972-73$ functions are useful in evaluating avalanche hazard, in that major cycles which pose a threat to surface transportation are distinguished from non-avalanche days.

The prediction of wet slides in the $1973-74$ season (Table $\mathrm{X}$ ) shows a sharp reduction in the number of misclassified avalanche days at the two-day integration, although this is based on a sample of only twelve days. The numbers of misclassified non-avalanche days are large in both the two- and three-day integrations. 
Table IX. Prediction of 1973-74 Dry avalanches

\begin{tabular}{|c|c|c|c|c|c|c|}
\hline \multirow{2}{*}{\multicolumn{2}{|c|}{$\begin{array}{c}\text { Stratum } \\
\text { (see Table II) }\end{array}$}} & \multirow[b]{2}{*}{$\begin{array}{l}\text { Number of } \\
\text { days prior }\end{array}$} & \multicolumn{4}{|c|}{ Percentage of days misclassified } \\
\hline & & & Avalanche days & $\begin{array}{c}\text { Avalanche days, } \\
\leqslant 2 \text { events }\end{array}$ & $\begin{array}{c}\text { Non-avalanche } \\
\text { days }\end{array}$ & $\begin{array}{l}\text { Variables } \\
\text { used }\end{array}$ \\
\hline 1. & I $\mathcal{N}=24,30^{*}$ & 5 & 37 & 25 & 27 & $3,4,5,6$ \\
\hline 2. & I $\mathcal{N}=28,3^{2}$ & 3 & 36 & 21 & 22 & I, $3,4,5,6$ \\
\hline 3 . & I $\mathcal{N}=28,3^{2}$ & 2 & 43 & 29 & 22 & I, $3,4,5,6$ \\
\hline 4. & II $\mathcal{N}=21,30$ & 5 & 33 & 24 & 27 & $3,4,5,6$ \\
\hline 5. & II $\mathcal{N}=25,32$ & 3 & $3^{2}$ & 24 & 22 & $\mathrm{I}, 3,4,5,6$ \\
\hline 6. & II $\mathcal{N}=25,3^{2}$ & 2 & $4^{0}$ & 28 & 22 & I, $3,4,5,6$ \\
\hline 7. & III $\mathcal{N}={ }_{\text {II }}, I_{1}$ & 5 & 0 & - & 27 & $2,7,9$ \\
\hline 8. & III $\mathcal{N}={ }_{13}, I_{3}$ & 3 & 8 & - & 23 & I, 2,4 \\
\hline 9 . & 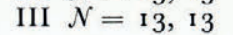 & 2 & 8 & - & 15 & $2,7,9$ \\
\hline
\end{tabular}

* Numbers refer to avalanche and non-avalanche day samples respectively.

Table X. Prediction of i973-74 Wet avalanches

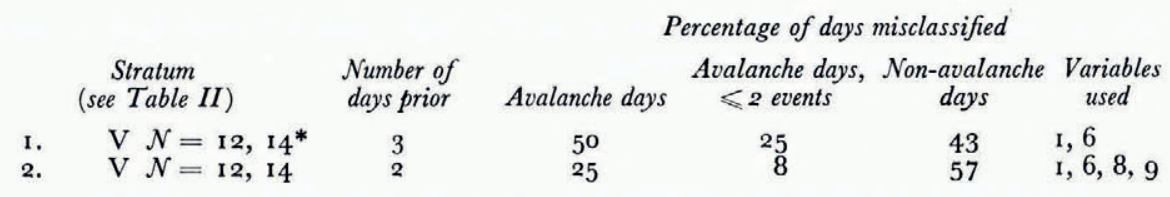

* Numbers refer to avalanche and non-avalanche day samples respectively.

\section{Conalusion}

The results of the preceding section indicate that the prediction of avalanche days using discriminant functions which are derived from a previous season requires a stratification of avalanche events by slide type and magnitude. The overall level of accuracy indicates that the method is generally most effective in predicting days that have at least three events greater than or equal to magnitude two. Since this type of day often has several soft-slab or wet-slab releases, many of which can reach the highway, the method may be used to assess the overall hazard along the highway at a given time.

Although a strict physical interpretation cannot be placed on all terms in the discriminant functions, nevertheless they serve as a starting point for real-time forecasting, using primarily meteorological variables. During subsequent seasons, forecasting will probably be based on discriminant functions derived from the observations of several preceding seasons. To date, the use of a single critical value, or discriminant index, to determine the status of a given day has possessed the obvious merit of simplicity in a field situation. In future applications, it is anticipated that estimates will be made of the probability of any given day belonging to each stratum of events in Table II.

\section{Acknowledgements}

The project from which this work derives is funded by the United States Bureau of Reclamation (Contract No. I4-o6-D-7I55 to Jack D. Ives). I wish to thank Nel Caine, Edward R. LaChapelle, and Wilford F. Weeks for their comments and criticisms of previous drafts of this paper. The advice and encouragement of Richard L. Armstrong and Don Bachman are also gratefully acknowledged.

MS. received Io April 1975 and in revised form ${ }^{15}$ March 1976 


\section{REFERENCES}

Bader, H., and Kuroiwa, D. 1962. The physics and mechanics of snow as a material. U.S. Cold Regions Research and Engineering Laboratory. Cold regions science and engineering. Hanover, N.H., Pt. II, Sect. B.

Bois, P., and others. [1975]. Multivariate data analysis as a tool for day-by-day avalanche forecast, [by] P. Bois, C. Obled and W. Good. [Union Géodésique et Géophysique Internationale. Association Internationale des Sciences Hydrologiques. Commission des Neiges et Glaces.] Symposium. Mécanique de la neige. Actes du colloque de Grindelwald, avril 1974 , p. 39 I-403. (IAHS-AISH Publication No. I I4.)

Hoel, P. G. 1971. Introduction to mathematical statistics. New York, John Wiley and Sons, Inc.

Hope, K. 1968. Methods of multivariate analysis. New York, Gordon and Breach.

Judson, A., and Erickson, B. J. 1973. Predicting avalanche intensity from weather data: a statistical analysis. U.S. Dept. of Agriculture. Forest Service. Research Paper RM-I 12.

Mellor, M. 1968. Avalanches. U.S. Cold Regions Research and Engineering Laboratory. Cold regions science and engineering. Hanover, N.H., Pt. III, Sect. A3d.

Van de Geer, J. P. 1971. An introduction to multivariate analysis for the social sciences. San Francisco, W. H. Freeman. 